\title{
Who Gets to (Re)Define Theatre?
}

\author{
Tereza Turzíková
}

Redefining Theatre: Theatre and Society in Transition. Freie Universität Berlin. 28-29 May 2021. Online.

In the light of the turbulent changes that have been manifesting themselves since last year in all spheres of social production due to the coronavirus pandemic, the intertwinement between economic, political, social transformation, and theatre practice is becoming significantly relevant. Although the conference Redefining Theatre organised by Freie Universität Berlin focused primarily on the shifts and transformations in theatre after 1989, the recent events, which have been affecting our perception of culture and society, have been hovering in the virtual air of the conference that united participants from all over the world. Using various case studies and examples from the European theatre practice of the 1990s, the conference contributors demonstrated ways in which contemporary theatre may be shaped and informed by non-aesthetic means. A profound question was posed: Who gets to (re)define theater? Though this question generates tension between theory and practice, culture and politics, as well as art and ideology, it also creates an intellectual dynamic which defined the entire conference.

The first panel Theatre and Social Crises focused on the interrelation between the past, the present, and the future, as well as the way the past can haunt the present, or the future can animate the past. Christopher Balme, who holds the chair in theatre studies at LMU Munich and is the author of numerous publications on theatre theory and performance studies, was the one who set the following mode of thinking about the future of theatre: theatre has to learn how to predict the future in order to survive both financially and aesthetically. It seems that COVID-19 has exacerbated pre-existing structural problems in theatre and finding solutions to them is not an easy task. One of the ways we can forecast the future of theater is via scenario-based exercises carried out at the John Hopkins Center for Health Security, where the public and experts meet to discuss possible scenarios of various crises humankind might encounter.

Following Balme's arguments, Andrea Tompa from the Babeș-Bolyai University contributed with her analysis of the last 30 years of Hungarian theatre. Seeing the development through the lens of Victor Turner's social drama, Tompa pointed out to the tension between the neoliberal idea of freedom and self-censorship in a growing authoritarian social climate. Ending her speech with the report of privatisation of the Theatre and Film Academy in Budapest, she ignited a debate on whether public or private institutions have more power in shaping a society.

During the second panel West-East Transitional Dynamics in Theatre, Anneli Saro (University of Tartu) focused on theatre culture in Estonia in the late $20^{\text {th }}$ century. Similarly to Tompa, she conceptualised the sociopolitical situation in Estonia via 
Turner's social drama, or '[...] units of harmonic or disharmonic processes, arising in conflict situations' (TURNER 1974: 37). In the Q\&A section, Saro drew attention to the theatricality of public life after 1989 , which seemed to have broadened the definition of theatre and redefined its function in a society.

A sociologist and social anthropologist from the University of Hamburg, Tanja Bogusz contributed further to our understanding of social function of theatre institutions using an example of the Volksbühne Berlin after 1989. Bogusz conducted an empirical study in the 2000s, interviewing theatre makers and employees to explore the dynamics between the post-socialist and capitalist mindset in theatre practice. Some of her main findings included the notion of 'antagonistic tension' within the Volksbühne and their adoption of post-utopian transgression and heterogeneity.

The panel Redefining Institutions and Identities contrasted Brandon Woolf's analysis of contemporary political theatre in Berlin with Jana Wild's elaboration on independent Slovak theater scene after 1989, which she had decided to share instead of her original paper focused on Shakespearean theatre productions in Slovakia. Woolf, an interdisciplinary theatre artist and professor at New York University, focused on how theatre scene in Berlin is connected to the municipal political situation in financial, institutional, or aesthetic way. He questioned the role of contemporary political theatre and the shift in powers between stage and state: what happens when public and political matters merge on stage nowadays - in a neoliberal climate without any official censorship? Jana Wild from the Academy of Performing Arts in Bratislava followed with her ex- planation of the shaping of Slovak theatre scene in the 1990s. She focused on how alternative and more radical forms of theatre slowly emerged in otherwise conservative theatrical culture.

The second day of the conference started off with the panel Theatre and the Changing Public Sphere. Paweł Sztarbowski from the Theatre Academy in Warsaw and Teatr Powszechny defined theatre as an efficient tool for rethinking the revolutions of 1989. Using the examples from Polish theatre practice, he examined the influence of conflicting ideologies of communism and neoliberalism on artistic practice. Sztarbowski concluded that after the rapid Westernisation of Polish culture in the 1990s, art practitioners have been lately returning to the alternative leftist narratives in search of the ways to redefine their national identity. Then Matthias Warstat (Freie Universität Berlin) explored the theatricality of street protests in 1989 Berlin and their relation to theatre. According to Warstat, a major issue defining the relation between revolutions and theatre is the inappropriate nature of performing on stage while the real drama is happening on the streets. Radka Kunderová from the same institution explored the endeavours of Czech theatre-makers after the Velvet Revolution, when the antagonistic tension between the artist and the authoritarian state disappeared and theatre had to be redefined under those new social and political circumstances. Based on the case study of Our Our Swaggerers (orig. Naši Naši Furianti, 1994) directed by Petr Lébl, Kunderová presented postmodern aesthetics and deconstruction as defining concepts of post-revolution theatre.

Subsequently, Meike Wagner (Stockholm University) offered a historical 
perspective on social and utopian function of theatre. She introduced the Privattheater-Gesellschaft Urania founded in 1792 in Berlin as a collectively owned institution based on democratic principles. In this example, Wagner stressed the possibility of participation and agency through theatre as we may know it today. In his theoretically saturated contribution, Tony Fisher (Royal Central School of Speech and Drama in London) examined the so-called 'closure of political theatre' in Western Europe. He also focused on new modes through which political theatre would have to confront the problem of its redefinition. Inspired by Althusser and Brecht, Fisher proposed a form of critical theatre which stages the difference between theatre and life and provides critique of theatre via its means, as claimed in the work of Thomas Ostermeier.

All in all, the conference exposed a complex interconnectedness between theatre and social transformation, as well as ideo- logical and economic influences on theatre practice and its reflection. As I had noticed throughout the conference, despite the provocative nature of contributions and openness to discussion, it failed to engage its participants in a dialogue. I personally found the silence of the audience worrisome as it uncovered uneasiness some students, guests, and even academicians might have felt having to face the scholars' images pinned at the top of their screens. Thus, the question of who gets to (re)define theatre then becomes acute: democratisation of knowledge and equal opportunity to contribute to discourse should not be discussed solely in our papers but should be actively practiced at our conferences.

\section{Bibliography}

TURNER, Victor. 1974. Dramas, Fields, and Metaphors: Symbolic Action in Human Society. Ithaca: Cornell University Press, 1974. 